\title{
PERLINDUNGAN KONSUMEN DALAM PENERAPAN BATAS KEWENANGAN BADAN PENYELESAIAN SENGKETA KONSUMEN MENYELESAIKAN PERKARA KONSUMEN (Studi Putusan No 481 K/Pdt.Sus-BPSK/2015)
}

\author{
Takenia Tifany \\ (Mahasiswa Program S1 Fakultas Hukum Universitas Tarumanagara) \\ (Email : takeniat@gmail.com)
}

\section{A.M Tri Anggraini}

(Corresponding Author)

(Dosen Fakultas Hukum Univesitas Trisakti, Meraih Sarjana Hukum dari Fakultas Hukum Universitas Gajahmada (1988), Magister Hukum dari Fakultas Hukum Universitas Tarumanagara (1995), Doktor Ilmu Hukum dari Fakultas Hukum Universitas Indonesia (2003)

(Email : anggraini1601@gmail.com)

\begin{abstract}
Consumer Protection Law regulates the legal protection of consumer and including Consumer Dispute Completion Firm who autorhized to resolve consumer disputes who feel harmed over the acts of business from people that sometimes arbitrary, but decisions taken by Consumer Dispute Completion Firm often incriminate business actors, and usually seem to exceed the limit of their authority even wrong in applying the law. Consumer Dispute Completion Firm's authority to adjudicate and decide a dispute is induced by Supreme Court's decision which makes Consumer Dispute Completion Firm's authority to limited. Therefore, the writer proposed an issue about how are the limits of Consumer Dispute Completion Firm's authority in adjudicate and decide a consumer disputes? And how are the implementation and Supreme Court's views regarding the limitation of Consumer Dispute Completion Firm's authority? The writer examines the problem using normative legal research methods that use secondary data. From the results of the research, it can be concluded that the limits of Consumer Dispute Completion Firm authority in solving consumer disputes are limited to the agreement between both parties. In sense the Supreme Court believes that all transactions based on an agreement become the jurisdiction of the court.
\end{abstract}

Keywords: Consumer Protection, limitation of authority, Consumer Dispute Completion Firm. 


\section{PENDAHULUAN}

\section{A. Latar Belakang}

Indonesia sebagai negara berkembang, yang industrinya baru mengalami tahap permulaan, perkembangan hukum perlindungan konsumennya belum berkembang sebagaimana di negara-negara maju. Hal ini disebabkan karena lazimnya perkembangan perlindungan konsumen merupakan akibat dari perkembangan industri suatu negara, yaitu industrialisasi massal. Lambannya perkembangan perlindungan konsumen di negara berkembang yang perkembangan perindustriannya baru pada tahap permulaan karena sikap pemerintah pada umumnya masih melindungi kepentingan industri yang merupakan faktor yang esensial dalam perkembangan suatu negara. ${ }^{1}$

Perkembangan perlindungan konsumen di Indonesia sendiri mulai muncul pada tahun 1970 yang ditandai dengan berdirinya Yayasan Lembaga Konsumen Indonesia (YLKI) pada bulan mei 1973. Perkembangan ke arah perlindungan konsumen di Indonesia selain munculnya lembaga-lembaga konsumen di Indonesia, juga ditandai dengan adanya perkembangan peraturan perundang-undangan dalam bidang perlindungan konsumen.

Perkembangan peraturan perundang-undangan dalam bidang perlindungan konsumen dapat pula dilihat pada hasil inventarisasi peraturan perundang-undangan yang dilakukan dalam rangka penyusunan rancangan akademik undang-undang tentang perlindungan konsumen. Hasil inventarisasi tersebut dibagi dalam delapan bidang, yaitu: bidang kesehatan dan obat-obatan, makanan dan minuman, alatalat elektronik, kendaraan bermotor, metrologi dan tera, industri, pengawasan mutu barang dan lingkungan hidup. Sebagai perkembangan terakhir dan sangat berarti adalah dengan lahirnya Undang-Undang Perlindungan Konsumen (UUPK), yang merupakan pengikat dari

\footnotetext{
${ }^{1}$ Ahmadi Miru, Prinsip-Prinsip Perlindungan Hukum Bagi Konsumen Di Indonesia, Cetakan ke-2, (Jakarta: PT RajaGrafindo Persada, 2013), hal. 67.
} 
berbagai ketentuan perundang-undangan di bidang perlindungan konsumen tersebut. ${ }^{2}$ Sebagai perkembangan terakhir dan sangat berarti adalah dengan lahirnya Undang-Undang Perlindungan Konsumen (UUPK), yang merupakan pengikat dari berbagai ketentuan perundangundangan di bidang perlindungan konsumen tersebut. ${ }^{3}$

Walaupun telah lahir Undang-Undang Perlindungan Konsumen (UUPK) yang sudah lama dinanti-nanti tersebut, persoalan mengenai perlindungan konsumen pada saat ini tidaklah kunjung berkurang, hal tersebut disebabkan karena masih rendahnya kesadaran masyarakat mengenai hak-haknya sebagai seorang konsumen dan perbuatan pelaku usaha yang beritikad tidak baik maupun karena kelalaiannya, ternyata berdampak serius kepada konsumen. Ganti kerugian yang dapat diberikan kepada konsumen yang mengalami kerugian hanya meliputi kerugian yang langsung dialami oleh konsumen karena mengkonsumsi suatu produk (hanya kerugian karena rusaknya produk) dan tidak meliputi akibat (kerugian harta benda) yang ditimbulkannya akibat penggunaan produk. ${ }^{4}$

Pengertian konsumen tidak terbatas pada konsumen yang sifatnya perorangan, akan tetapi dapat pula yang sifatnya badan hukum atau perusahaan yang dikategorikan sebagai pengguna atau pemakai suatu sarana atau suatu fasilitas barang dan/atau jasa yang terakhir. Faktor utama yang seringkali menjadi kelemahan konsumen adalah tingkat kesadaran konsumen akan haknya masih rendah. ${ }^{5}$ Pakar masalah konsumen di Belanda, Hondius menyimpulkan, para ahli hukum pada umumnya sepakat mengartikan konsumen sebagai, pemakai produksi terakhir dari benda dan jasa. Konsumen diartikan tidak hanya individu (orang), tetapi juga suatu perusahaan yang menjadi pembeli atau

\footnotetext{
${ }^{2}$ Ibid., hal 68.

${ }^{3}$ Ibid., hal 68.

${ }^{4}$ Ibid., hal 69.

${ }^{5}$ Adrian Sutedi, Tanggung Jawab Produk Dalam Hukum Perlindungan Konsumen, Cetakan ke-1.(Bogor: Ghalia Indonesia, 2008), hal. 1.
} 
pemakai terakhir. ${ }^{6}$ Di Amerika Serikat, pengertian konsumen meliputi "korban produk yang cacat" yang bukan hanya meliputi pembeli, melainkan juga korban yang bukan pembeli, namun pemakai, bahkan korban yang bukan pemakai memperoleh perlindungan yang sama dengan pemakai. ${ }^{7)}$ Pengertian konsumen sendiri di Indonesia diatur dalam Pasal 1 ayat (2) UUPK, yaitu setiap orang pemakai barang dan/ jasa yang tersedia dalam masyarakat, baik bagi kepentingan diri sendiri, keluarga, orang lain maupun makhluk hidup lain dan tidak diperdagangkan.

UUPK mengatur mengenai perlindungan hukum terhadap konsumen dan termaksud di dalamnya mengatur mengenai Badan Penyelesaian Sengketa Konsumen (BPSK) yang berwenang untuk menyelesaikan sengketa konsumen yang merasa dirugikan atas tindakan pelaku usaha yang terkadang sewenang-wenang. BPSK adalah sebuah alternatif penyelesaian sengketa konsumen di luar pengadilan untuk menyelesaikan sengketa konsumen dengan perkara gugatan sederhana (small claim court) dengan nilai gugatan materiil paling banyak Rp 200.000.000,- (Dua Ratus Juta Rupiah) yang diselesaikan dengan tata cara dan pembuktian sederhana.

Di dalam Pasal 49 UUPK tercantum bahwa "Pemerintah membentuk badan penyelesaian sengketa konsumen di Daerah Tingkat II untuk penyelesaian sengketa konsumen di luar pengadilan". BPSK dibentuk untuk menindaklanjuti UUPK yang berlaku efektif sejak tanggal 21 April 2000. Namun keputusan yang diambil oleh BPSK seringkali memberatkan pelaku usaha, dan biasanya terkesan melampaui batas kewenangan bahkan salah dalam menerapkan hukumnya. Melampaui batas kewenangan dan bahkan salah dalam menerapkan hukumnya ini tercermin di dalam Putusan Mahkamah Agung Nomor No

\footnotetext{
${ }^{6}$ Shidarta, Hukum Perlindungan Konsumen Indonesia,. Cetakan ke-3, (Jakarta: PT Grasindo, 2006), hal. 4.

${ }^{77}$ Ahmadi Miru, Op.Cit., hal. 21.
} 
481 K/Pdt.Sus-BPSK/2015 antara PT TOYOTA ASTRA FINANCIAL SERVICES CABANG PADANG, melawan IZWA FARIZAL selaku konsumen pengguna jasa pengkreditan.

Dalam perkara ini pihak pelaku usaha yakni PT Toyota Astra Financial Services Cabang Padang menilai bahwa putusan yang dikeluarkan oleh BPSK Kota Padang telah salah dalam penerapan hukumnya dan bertindak di luar batas kewenangan. PT Toyota Astra Financial Services Cabang Padang menilai bahwa dalam perkara ini konsumen telah melakukan wanprestasi berupa penunggakan pembayaran angsuran selama lebih dari enam (6) bulan dengan objek perjanjian dua (2) buah unit mobil toyota dyna wu 42 HT3S Dump dengan masing-masing objek didasari oleh perjanjian pembiayaan yang berbeda.

PT Toyota Astra Financial Services Cabang Padang selaku pelaku usaha menilai putusan yang dikeluarkan oleh BPSK adalah putusan yang sangat ceroboh, melampaui batas kewenangan bahkan salah dalam penerapan hukumnya. PT Toyota Astra Financial Services Cabang Padang merasa dirugikan karena jika didasari pada perjanjian pembiayaan No. 922601-13 tertanggal 31 agustus 2013 dan perjanjian pembiayaan No. 922602-13 tanggal 30 september 2013 hutang pokok yang dimiliki oleh konsumen dari masing-masing perjanjian tersebut adalah sebesar Rp 274.243.720.- (dua ratus tujuh puluh empat juta dua ratus empat puluh tiga ribu tujuh ratus dua puluh rupiah), dan dalam pasal 15 perjanjian pembiayaan No. 922601-13 tertanggal 31 agustus 2013 dan perjanjian pembiayaan No. 922602-13 tanggal 30 september 2013 disebutkan dengan jelas bahwa apabila terjadi perlselisihan atau perbedaan pendapat maka akan diselesaikan di Pengadilan Negeri (PENGADILAN NEGERI) wilayah hukum kreditur yaitu PENGADILAN NEGERI Padang.

Berdasarkan latarbelakang di atas, Penulis ingin mendalami dan menuangkan kasus tersebut dalam bentuk proposal dengan judul 
"PERLINDUNGAN KONSUMEN DALAM PENERAPAN BATAS KEWENANGAN BADAN PENYELESAIAN SENGKETA KONSUMEN MENYELESAIKAN PERKARA KONSUMEN (Studi Putusan No 481 K/Pdt.Sus-BPSK/2015)”.

\section{B. Perumusan Masalah}

Berdasarkan pemaparan latar belakang yang telah diuraikan di atas, maka untuk lebih memfokuskan penelitian ini dirumuskan permasalahan sebagai berikut :

1. Bagaimana Perlindungan Hukum Bagi Konsumen Terhadap Pengembang Dan Pihak Bank Yang Tidak Memenuhi Kewajibannya Terhadap Konsumen?

2. Upaya Hukum Yang Dapat Dilakukan Konsumen Dalam Hal Terjadi Pembongkaran Rumah?

\section{Metode Analisis}

Penelitian hukum merupakan suatu kegiatan ilmiah yang didasarkan pada metode sistematika dan pemikiran tertentu yang bertujuan untuk mempelajari satu atau beberapa gejala hukum tertentu dengan jalan menganalisisnya. ${ }^{8}$

\section{Tipe Penelitian}

Penelitian hukum yang dilakukan dengan cara meneliti bahan pustaka atau data sekunder belaka, dapat dinamakan penelitian hukum normatif atau penelitian hukum kepustakaan. ${ }^{9}$ Jenis penelitian hukum normatif atau kepustakaan yang dipergunakan dalam penelitian ini adalah penelitian terhadap asas-asas hukum. Penelitian terhadap asas-asas hukum dilakukan terhadap kaidah-

\footnotetext{
${ }^{8}$ Soerjono Soekanto, Pengantar Penelitian Hukum, Cetakan ke-3, (Jakarta: UI Press, 1986), hal. 43.

${ }^{9}$ Soerjono Soekanto dan Sri Mamudji, Penelitian Hukum Normatif, Indonesia, (Jakarta: Rajagrafindo Persada, 2006), hal. 14.
} 
kaidah hukum, yang merupakan patokan-patokan berperilaku atau bersikap tidak pantas. ${ }^{10}$

\section{Sifat Penelitian}

Sifat dari penelitian ini adalah deskriptif, ${ }^{11}$ yaitu berupa penelitian yang menggambarkan fenomena atas permasalahan tertentu dan pada dasarnya dimaksudkan untuk memberikan data yang seteliti mungkin tentang manusia, keadaan atau gejala-gejala lainnya.

\section{Jenis Data}

Jenis data yang dipergunakan dalam penelitian ini adalah data sekunder, yaitu data yang sumbernya diperoleh dari kajian kepustakaan dan dilaksanakan dengan menginterventarisir seluruh data yang ada kaitannya dengan objek penulisan skripsi ini. Adapun bahan-bahan hukum yang dipergunakan dalam penulisan ini meliputi: ${ }^{12}$

a. Bahan Hukum Primer

Bahan Hukum Primer, yaitu bahan-bahan hukum yang mengikat diantaranya adalah Peraturan-peraturan, UndangUndang Nomor 8 Tahun 1999 tentang Perlindungan Konsumen (UUPK), Undang-Undang Nomor 30 tahun 1999 tentang Arbitrase dan Alternatif Penyelesaian Sengketa, Keputusan Menteri Perindustrian Dan Perdagangan Republik Indonesia Nomor : 350/MPP/Kep/12/2001 (Kepmen Perindag 350/2001) tentang Pelaksanaan Tugas dan Wewenang Badan Penyelesaian Sengketa Konsumen, Putusan Mahkamah Agung Nomor 1240 K/Pdt.Sus-BPSK/2017.

b. Bahan Hukum Sekunder

Bahan hukum sekunder, yang memberikan penjelasan mengenai bahan hukum primer, seperti, rancangan undang-

\footnotetext{
${ }^{10}$ Ibid., hal 62.

${ }^{11}$ Soerjono Soekanto, Op.Cit., hal. 10.

${ }^{12}$ Ibid., hal 12.
} 
undang, hasil-hasil penelitian, hasil karya dari kalangan hukum, dan seterusnya. ${ }^{13}$

\section{Teknik pengumpulan data}

Teknik pengumpulan data yang dipergunakan dalam penelitian ini adalah dengan studi dokumen atau bahan pustaka (Library Research).

\section{Teknik Analisis Bahan Hukum}

Teknis analisis bahan hukum yang dipergunakan untuk mendapatkan argumentasi akhir yang berupa jawaban terhadap permasalahan penelitian ini adalah Teknik Dekriptif, yaitu pertama peneliti akan memaparkan apa adanya tentang suatu peristiwa hukum atau kondisi hukum, deskripsi diberikan dengan apa adanya tanpa disertai dengan tanggapan atau pendapat pribadi peneliti. ${ }^{14)}$

\section{Penarikan Kesimpulan}

Penarikan Kesimpulan yang dipergunakan dalam penelitian ini adalah penalaran deduktif, yaitu sebuah proses penalaran untuk menarik kesimpulan berupa prinsip atau sikap yang berlaku khusus berdasarkan atas fakta - fakta yang bersifat umum. Proses penalaran ini disebut deduksi, kesimpulan deduktif di bentuk dengan cara deduksi. Di mulai dari hal - hal umum menuju kepada hal - hal yang khusus atau hal - hal yang lebih rendah proses pembentukan kesimpulan deduktif tersebut dapat di mulai dari suatu dalil atau hukum menuju kepadal hal - hal yang kongkrit. ${ }^{15}$

\footnotetext{
${ }^{13}$ Soerjono Soekanto dan Sri Mamudji, Op.Cit., hal. 13.

${ }^{14}$ I Made Pasek Diantha, Metodelogi Penelitian Hukum Normatif Dalam Justifikasi Teori Hukum, (Jakarta: Kencana Prenada Media Group, 2016), hal.152.

${ }^{15}$ Naringgoyudo, "Perbedaan Deduktif dan Induktif", https://naringgoyudo.wordpress.com/2015/03/24/perbedaan-deduktif-dan-induktiff, diakses tanggal 24 Maret 2015.
} 


\section{PEMBAHASAN}

\section{A. Kasus Posisi}

Kasus yang terdapat dalam putusan BPSK ini berawal dari pembuatan perjanjian pembiayaan No. 922601-13 tertanggal 31 agustus 2013 dan perjanjian pembiayaan No. 922602-13 tanggal 30 september 2013 dengan objek masing-masing perjanjian tersebut adalah mobil Toyota dyna wu 42 HT3S Dump, bedasarkan perjanjian tersebut konsumen wajib membayar tepat waktu jatuh tempo pembayaran angsuran pembiayaan yaitu setiap tanggal 31 setiap bulannya.

Dari angsuran pertama sampai angsuran ke 7 (tujuh) konsumen lancar melakukan pembayaran akan tetapi pada angsuran ke 8 (delapan) yang jatuh tempo pada tanggal 31 maret 2014 dibayar oleh konsumen pada tanggal 26 mei 2014, kemudian untuk angsuran ke 9 (Sembilan ) jatuh tempo pada tanggal 30 april 2014 dibayar oleh kosumen pada tanggal 22 agustus 2014 dan seterusnya sudah tidak tepat waktu sebagaimana yang telah diperjanjikan dan untuk angsuran yang ke 12 (duabelas) jatuh tempo tanggal 31 juli 2014 konsumen tidak lagi membayar angsurannya sampai objek jaminan fidusia di eksekusi oleh PT Toyota Astra Financial Services Cabang Padang tertanggal 15 januari 2015 yang dimana konsumen sudah terlambat membayar angsuran lebih dari 6 (enam) bulan.

Atas perbuataan yang dilakukan oleh pelaku usaha tersebut, konsumen merasa di rugikan dan mengajukan gugatan ke BPSK Kota Padang, yang dimana dalam putusannya BPSK Kota Padang memenangkan Izwa Farizal selaku konsumen dengan amar putusan sebagai berikut:

1. Mengabulkan tuntutan konsumen berupa pengembalian satu unit kendaran dari 2 unit yang menjadi objek perkara dengan ketentuan segala hutang piutang antara konsumen dan pelaku usaha selesai. 
Kasus ini kemudian dilanjutkan oleh pelaku usaha ke Pengadilan Negeri Kelas I. A Padang dengan mengajukan permohonan keberatan terhadap putusan BPSK (Nomor 010/PTS-BPSK-PDG/ARBT/III/2015). Namun Pengadilan Negeri Padang memberikan amar putusan sebagai berikut: ${ }^{16)}$

a) Menolak permohonan keberatan dari pelaku usaha tersebut;

b) Menghukum pelaku usaha untuk membayar biaya perkara yang sampai hari ini ditetapkan sejumlah Rp401.000,00 (empat ratus satu ribu rupiah rupiah);

Tidak puas atas putusan Pengadilan Negeri Padang (Nomor 55/Pdt.Sus-BPSK/2015/PENGADILAN NEGERI.Pdg.) tersebut PT Toyota Astra Financial Services Cabang Padang mengajukan kasasi ke Mahkamah Agung. Kemudian Mahkamah Agung memberikan amar putusan berupa:

1) Mengabulkan permohonan kasasi dari Pemohon Kasasi: PT Toyota Astra Financial Services Cabang Padang, tersebut;

2) Membatalkan Putusan PENGADILAN NEGERI Padang Nomor 55/Pdt.Sus-BPSK/2015/PENGADILAN NEGERI.Pdg., tanggal 20 Mei 2015.

Selain itu Majelis juga menyatakan bahwa:

a. Menyatakan BPSK Kota Padang tidak berwenang memeriksa dan memutus perkara a quo;

b. Menghukum Termohon Kasasi/Termohon Keberatan (dahulu konsumen) untuk membayar biaya perkara pada semua tingkat peradilan, yang dalam tingkat kasasi ditetapkan sebesar Rp500.000,00 (lima ratus ribu rupuah).

\footnotetext{
${ }^{16)}$ Ibid., hal 20.
} 


\section{B. Analisa}

\section{Batas Kewenangan Badan Penyelesaian Sengketa Konsumen} Menyelesaikan Perkara Konsumen Dalam Putusan No 481 K/Pdt.Sus-BPSK/2015

UUPK membentuk suatu lembaga dalam hukum perlindungan konsumen, yaitu BPSK. Pasal 1 ayat (11) UUPK menyatakan bahwa BPSK adalah badan yang bertugas menangani dan menyelesaikan sengketa antara pelaku usaha dan konsumen. BPSK sebenarnya dibentuk untuk menyelesaikan kasus-kasus sengketa konsumen yang berskala kecil dan bersifat sederhana. ${ }^{17}$ Berdasarkan Pasal 2 Kepmenperindag No. 350/MPP/KEP/2001, BPSK berfungsi untuk menangani dan menyelesaikan sengketa konsumen di luar pengadilan.

Keberadaan BPSK dapat menjadi bagian dari pemerataan keadilan, terutama bagi konsumen yang merasa dirugikan oleh pelaku usaha/produsen, karena sengketa diantara konsumen dan pelaku usaha/produsen, biasanya nominalnya kecil sehingga tidak mungkin mengajukan sengketanya di pengadilan karena tidak sebanding antara biaya perkara dengan besarnya kerugian yang akan dituntut. Pembentukan BPSK sendiri didasarkan pada adanya kecendrungan masyarakat yang segan untuk beracara di pengadilan karena posisi konsumen yang secara sosial dan finansial tidak seimbang dengan pelaku usaha. ${ }^{18}$

Putusan yang dikeluarkan BPSK dapat berupa perdamaian, gugatan ditolak, atau gugatan dikabulkan. Dalam hal gugatan dikabulkan, maka dalam amar putusan ditetapkan kewajiban yang harus dilakukan oleh pelaku usaha, berupa pemenuhan ganti rugi

\footnotetext{
${ }^{17}$ Susanti Adi Nugroho, Proses Penyelesaian Sengketa Konsumen Ditinjau Dari Hukum Acara Serta Kendala Implementasinya, Cetakan Ke-2. (Jakarta: kencana, 2008), hal.74.

${ }^{18}$ Sularsi, Penyelesaian Sengketa Konsumen Dalam Undang-Undang Perlindungan Konsumen, (Jakarta: Yayasan Lembaga Konsumen Indonesia, 2001), hal. 86-87.
} 
dan/atau sanksi administratif berupa penetapan ganti rugi paling banyak sebesar Rp 200.000.000,- (Dua Ratus Juta Rupiah). ${ }^{19}$

Jika putusan majelis BPSK dapat diterima oleh kedua belah pihak yang bersengketa, maka putusan BPSK tersebut bersifat final and binding (final dan mengikat) kedua belah pihak, sehingga atas putusan tersebut tidak perlu diajukan upaya keberatan ke Pengadilan Negeri.

Namun atas kewenangan BPSK menangani suatu sengketa tersebut, jika dikaitkan dengan putusan Mahkamah Agung yang membatasi kewenangan BPSK, BPSK tidak berwenang mengadili sengketa yang timbul dari pelaksanaan perjanjian atau wanprestasi, sehingga penyelesaiannya merupakan kewenangan Pengadilan Negeri bukan kewenangan BPSK.

Dalam Pasal 1338 Kitab Undang-Undang Hukum Perdata (KUHPer) menegaskan bahwa semua perjanjian yang dibuat secara sah berlaku sebagai undang-undang bagi mereka yang membuatnya. Artinya selama ada kesepakatan antara para pihak mengenai harga atas barang dan/ atau jasa antara konsumen dan pelaku usaha maka perjanjian tersebut mengikat kecuali terdapat kekhilafan atau penipuan atas diri konsumen. ${ }^{20}$

Berdasarkan ketentuan dalam Pasal 1234 KUHPer, yang dimana prestasi dari suatu perjanjian terdiri dari:

a. Memberikan sesuatu;

b. Berbuat sesuatu;

c. Tidak berbuat sesuatu.

Yang dimaksud dengan prestasi dari suatu perjanjian adalah pelaksanaan terhadap hal-hal yang telah diperjanjikan atau yang

\footnotetext{
${ }^{19}$ Andrian Sutedi, Op.Cit., hal. 25.

${ }^{20}$ Anonim,"Perlindungan Hak-Hak Konsumen Listrik Di Indonesia Menurut Undang-Undang Nomor $8 \quad$ Tahun $1999 \quad$ Tentang Perlindungan Konsumen”, https://ayobelajarhaki.wordpress.com/2012/05/04/perlindungan-hak-hak-konsumen-listrik-diindonesia-menurut-undang-undang-nomor-8-tahun-1999-tentang-perlindungan-konsumen/, diakses tanggal 4 Mei 2008.
} 
telah ditulis dalam suatu perjanjian oleh kedua belah pihak yang telah mengikatkan diri untuk itu. ${ }^{21}$

Sedangkan wanprestasi adalah kenyataan sebaliknya dari prestasi. Dalam hal ini, jika dalam pretasi, isi dijalankan atau dipenuhi oleh para pihak, maka dalam wanprestasi tidak menjalankan atau memenuhi isi perjanjian yang bersangkutan. Wanpretasi dari suatu perjanjian berupa:

1) Tidak memenuhi prestasi;

2) Tidak sempurna memenuhi prasasti;

3) Terlambat memenuhi prestasi. ${ }^{22}$

Selanjutnya, dalam hubungan dengan wanprestasi terhadap perjanjian, terdapat beberapa konstruksi hukum sebagai berikut:

a) Terminasi perjanjian;

Yang dimaksud dengan terminasi perjanjian adalah suatu tindakan pemutusan (tidak melanjutkan lagi) suatu perjanjian di tengah jalan, meskipun sesuai ketentuan dalam perjanjian tersebut, perjanjian yang bersangkutan masih harus dijalankan oleh kedua belah pihak. ${ }^{23}$

b) Restorasi perjanjian;

Yang dimaksud dengan restorasi adalah hak dari pihak yang melakukan wanprestasi terhadap suatu perjanjian dimana karena prestasi tersebut, pihak lain memutuskan perjanjian tesebut, tetapi dengan pemutusan perjanjian oleh pihak lain tersebut, ada sebagian dari prestasi dari pelaku wanprestasi yang sudah diberikan kepada pihak yang dirugikan karena pretasi tersebut. Maka pihak lain (yang memutus perjanjian) yang telah dirugikan karena wanprestasi tersebut wajib mengembalikan prestasi kepada pelaku wanprestasi tersebut. Tindakan

\footnotetext{
${ }^{21}$ Munir Fuady, Konsep Hukum Perdata, Cetakan ke-1. (Jakarta: PT RajaGrafindo Persada, 2014), hal. 207.

${ }^{22}$ Ibid., hal. 207.

${ }^{23}$ Ibid., hal. 209.
} 
pengembalian pretasi dalam bentuk restorasi tersebut dilakukan dengan dua jalan, yaitu : pengembalian benda secara fisik, dan pembayaran kompensasi. $^{24}$

c) Repudiasi perjanjian;

Yang dimaksud dengan repudiasi adalah suatu manifestasi atau pernyataan mengenai ketidaksediaan atau ketidakmampuan untuk memenuhi prestasi dari suatu perjanjian, meskipun sebelumnya prestasi tersebut telah disetujui untuk dilaksanakan, dimana manifestasi atau pernyataan tersebut dibuat sebelum tibanya waktu melaksanakan prestasi atau melaksanakan perjanjian tersebut. ${ }^{25}$

d) Resisi perjanjian

Yang dimaksud dengan tindakan resisi terhadap suatu perjanjian adalah pembatalan suatu perjanjian karena memang perjanjian tersebut dapat dibatalkan, sehingga perjanjian tersebut menjadi dalam keadaan "status quo". ${ }^{26}$

e) Reformasi perjanjian.

Yang dimaksudkan dengan reformasi perjanjian adalah bahwa terhadap perjanjian tersebut dibuat perbaikan-perbaikan agar perjanjian tersebut sesuai dengan maksud para pihak. Jadi berbeda dengan resisi yang hendak membatalkan perjanjian, maka dengan tindakan reformasi, yang hendak dilakukan adalah untuk mempertahankan perjanjian yang ada. ${ }^{27}$

Dalam kasus tersebut, seharusnya BPSK menyatakan tidak berwenang untuk mengadili sengketa konsumen, hal ini dikarenakan pada dasarnya dalam kasus ini terdapat hubungan hukum berupa perjanjian pembiayaan No. 922601-13 tertanggal 31 agustus 2013 dan perjanjian pembiayaan No. 922602-13 tanggal 30 september

\footnotetext{
${ }^{24}$ Ibid., hal. 210-211.

${ }^{25}$ Ibid., hal. 211.

${ }^{26}$ Ibid., hal. 213.

${ }^{27}$ Ibid., hal. 213-214.
} 
2013 antara PT Toyota Astra Financial Services Cabang Padang dengan Izwa Farizal yang dimana berdasarkan Pasal 1338 KUHPer semua perjanjian yang dibuat secara sah berlaku sebagai undangundang bagi mereka yang membuatnya. Dalam Pasal 15 perjanjian pembiayaan No. 922601-13 tertanggal 31 agustus 2013 dan perjanjian pembiayaan No. 922602-13 tanggal 30 september disebutkan dengan jelas bahwa apabila terjadi perselisihan atau perbedaan pendapat maka akan diselesaikan di Pengadilan Negeri wilayah hukum kreditur yaitu PENGADILAN NEGERI padang.

Berdasarkan hal tersebut diatas, sudah sangat jelas bahwa kewenangan untuk mengadili sengketa konsumen ini merupakan kewenangan dari PENGADILAN NEGERI dan bukan merupakan kewenangan BPSK, sudah seharusnya jika BPSK menyatakan tidak berwenang untuk mengadili dan memutus perkara ini. Penulis berpendapat bahwa jika didasari pada teori kewenangan, Pasal 1338 KUHPer dan Pasal 15 perjanjian pembiayaan No. 922601-13 tertanggal 31 agustus 2013 dan perjanjian pembiayaan No. 92260213 tanggal 30 september 2013, kewenangan mengadili sudah seharusnya jatuh kepada PENGADILAN NEGERI.

\section{Penerapan Dan Pandangan Mahkamah Agung (MA) Mengenai Pembatasan Kewenangan BPSK}

Pelanggaran terhadap perlindungan konsumen kerap kali dilakukan oleh pelaku usaha yang beritikad tidak baik maupun karena kelalaiannya, ternyata berdampak serius kepada konsumen. Namun terkadang pelanggaran tersebut tidak hanya disebabkan karena kelalaian ataupun tindakan pelaku usaha yang beritikad tidak baik, pelangaran terhadap perlindungan konsumen tersebut juga terkadang disebabkan karena tindakan/ perbuatan konsumen itu sendiri. 
UUPK lahir dan dibentuk untuk dapat meningkatkan kesejahteraan masyarakat banyak dan sekaligus mendapatkan kepastian atas barang dan/atau jasa yang diperoleh dari perdagangan tanpa mengakibatkan kerugian konsumen. Konsumen dalam hal ini diartikan tidak hanya individu (orang), tetapi juga suatu perusahaan yang menjadi pembeli atau pemakai terakhir. ${ }^{28}$

Perlindungan konsumen itu sendiri berdasarkan Pasal 1 ayat (1) UUPK ialah segala upaya yang menjamin adanya kepastian hukum untuk memberi perlindungan kepada konsumen. Perlindungan konsumen pada dasarnya bertujuan untuk:

a. Meningkatkan kesadaran, kemampuan dan kemandirian konsumen untuk melindungi diri;

b. Mengangkat harkat dan martabat konsumen dengan cara menghindarkannya dari ekses negatif pemakaian barang dan/atau jasa;

c. Meningkatkan pemberdayaan konsumen dalam memilih, menentukan dan menuntut hak-haknya sebagai konsumen;

d. Menciptakan sistem perlindungan konsumen yang mengandung unsur kepastian hukum dan keterbukaan informasi serta akses untuk mendapatkan informasi;

e. Menumbuhkan kesadaran pelaku usaha mengenai pentingnya perlindungan konsumen sehingga tumbuh sikap yang jujur dan bertanggung jawab dalam berusaha;

f. Meningkatkan kualitas barang dan/atau jasa yang menjamin kelangsungan usaha produksi barang dan/atau jasa, kesehatan, kenyamanan, keamanan, dan keselamatan konsumen.

Untuk mendapatkan perlindungan, konsumen yang merasa dirugikan dapat mengajukan gugatan melalui proses litigasi maupun menyelesaikan sengketa diluar pengadilan dengan cara damai ataupun melalui lembaga yang berwenang dalam hal ini adalah BPSK. Penting untuk diketahui bahwa terdapat 2 (dua) jenis perlindungan yang diberikan kepada konsumen, yaitu: ${ }^{29}$

\footnotetext{
${ }^{28}$ Shidarta, Op.Cit., hal. 4.

${ }^{29}$ Anonim,"Perlindungan Hak-Hak Konsumen Listrik Di Indonesia Menurut UndangUndang Nomor 8 Tahun 1999 Tentang Perlindungan Konsumen”, https://ayobelajarhaki.wordpress.com/2012/05/04/perlindungan-hak-hak-konsumen-listrik-di-
} 
1) Perlindungan Hukum Preventif

Perlindungan hukum preventif ialah, bentuk perlindungan hukum dimana kepada masyarkat diberikan kesempatan untuk mengajukan keberatan (inspraak) atau pendapatnya sebelum suatu keputusan pemerintah mendapa bentuk yang definitif.

2) Perlindungan Hukum Kuratif

Perlindungan hukum kuratif yakni, bentuk perlindungan hukum yang lebih ditujukan dalam menyelesaikan sengketa.

Namun atas keputusan yang diambil oleh BPSK tersebut seringkali memberatkan pelaku usaha, dan biasanya terkesan melampaui batas kewenangan bahkan salah dalam menerapkan hukumnya. BPSK seringkali tidak mempertimbangkan dalil-dalil dan alasan hukum pelaku usaha serta bukti-bukti yang telah pelaku usaha ajukan dalam persidangan, dan dalam memutus suatu sengketa konsumen BPSK kerap kali hanya berpegang pada UUPK saja, BPSK tidak memperhatikan asas Lex specialis derogat legi generali yang menyatakan bahwa hukum yang bersifat khusus (lex specialis) mengesampingkan hukum yang bersifat umum (lex generalis).

Sejak akhir 2013 mulai terjadi perubahan pandangan hukum di Mahkamah Agung. Mahkamah Agung menilai bahwa sengketa yang terjadi dalam pelaksanaan perjanjian pembiayaan konsumen baik berdasarkan perjanjian fidusia maupun hak tanggungan bukanlah termasuk sengketa konsumen, oleh karenanya BPSK tidak memiliki kewenangan untuk mengadilinya. Sengketa yang timbul dari pelaksanaan perjanjian pembiayaan konsumen tersebut menurut Mahkamah Agung merupakan sengketa perjanjian yang mana hal tersebut merupakan kewenangan dari Pengadilan Negeri. Hal

indonesia-menurut-undang-undang-nomor-8-tahun-1999-tentang-perlindungan-konsumen/, diakses tanggal 4 Mei 2008. 
tersebut tercermin dalam putusan Mahkamah Agung No 481 K/Pdt.Sus-BPSK/2015, yang dijadikan sebagai yurisprudensi bagi para hakim yang lain untuk menyelesaikan perkara yang sama. ${ }^{30}$

Putusan Mahkamah Agung No 481 K/Pdt.Sus-BPSK/2015 tersebut diperkuat dengan 10 (sepuluh) keputusan lain yang menyatakan BPSK tidak berwenang mengadili sengketa yang timbul dari pelaksanaan perjanjian fidusia/hak tanggungan, berikut ini daftar putusan Mahkamah Agung tersebut:

a) Putusan No 572 K/Pdt.Sus-BPSK/2014 tertanggal 18 November 2014, di dalam putusannya pada halaman 30, dalam pertimbangannya Mahkamah Agung menyimpulkan "bahwa masalah yang diselesaikan oleh BPSK Bengkayang telah berada “diluar" kewenangan yang diberikan kepadanya".

b) Putusan No 472 K/Pdt.Sus-BPSK/2014 tertanggal 17 Februari 2015, di dalam putusannya pada halaman 14, dalam pertimbangannya Mahkamah Agung menyatakan "bahwa Badan Penyelesaian Sengketa Konsumen (BPSK) Kota Tasikmalaya tidak berwenang untuk memeriksa dan mengadili perkara ini”.

c) Putusan No 25 K/Pdt.Sus-BPSK/2015 tertanggal 27 Maret 2015, di dalam putusannya pada halaman 7 , dalam pertimbangannya Mahkamah Agung menyatakan "bahwa dengan demikian BPSK tidak berwenang mengadili perkara perselisihan yang timbul dari perjanjian kredit atau masalah wanprestasi”.

d) Putusan No 341 K/Pdt.Sus-BPSK/2015 tertanggal 18Juni 2015, di dalam putusannya pada halaman 27 , dalam pertimbangannya Mahkamah Agung menyatakan amar Putusan BPSK Kabupaten Batubara ke-3 dan ke-7 BPSK adalah mengenai pelaksanaan isi Perjanjian Pembiayaan Konsumen, "sehingga perkara yang

\footnotetext{
${ }^{30}$ Kolom Arsil,"Sikap Hukum MA atas Kewenangan BPSK Mengadili Sengketa Lembaga Pembiayaan dan Nasabah", http://www.hukumonline.com/berita/baca/lt59f2b4473d8f0/sikaphukum-ma-atas-kewenangan-bpsk-mengadili-sengketa-lembaga-pembiayaan-dan-nasabah, 27 Oktober 2017.
} 
diperiksa dan diputus oleh BPSK Batubara dalam perkara a quo bukanlah sengketa konsumen, karena itu BPSK Kabupaten Batubara tidak berwenang memeriksa dan memutus perkara $a$ quo".

e) Putusan No 549 K/Pdt.Sus-BPSK/2015 tertanggal 22 Oktober 2015, di dalam putusannya pada halaman 12, dalam pertimbangannya Mahkamah Agung menyatakan "BPSK tidak memiliki kewenangan untuk mengadili perselisihan yang timbul dari Perjanjian Kredit dengan jaminan karena perselisihan tersebut tidak termasuk sengketa konsumen dan produsen yang diatur dalam Undang-Undang Perlindungan Konsumen”.

f) Putusan No $770 \mathrm{~K} / \mathrm{Pdt}$.Sus-BPSK/2015 tertanggal 22 Desember 2015, di dalam putusannya pada halaman 22, dalam pertimbangannya Mahkamah Agung menyatakan "bahwa sesuai dengan fakta persidangan sengketa a quo adalah sengketa pelaksanaan perjanjian kredit, sehingga BPSK Batu Bara tidak berwenang memeriksa dan memutus perkara a quo".

g) Putusan No 188 K/Pdt.Sus-BPSK/2016 tertanggal 31 Mei 2016, di dalam putusannya pada halaman 17 , dalam pertimbangannya Mahkamah Agung menyatakan "Bahwa ternyata antara Pemohon Keberatan dengan TermohonKeberatan dalam perkara a quo, telah terikat dalam perjanjian pembiayaan konsumen, dimana terbukti Termohon Keberatan berpotensi "wanprestasi" terhadap Pemohon Keberatan, sehingga BPSK Kabupaten Batu Bara menjadi tidak berwenang untuk memeriksa dan mengadili perkara a quo, untuk itu putusan Judex Facti tidak dapat dipertahankan lagi dan harus dibatalkan”.

h) Putusan No 56 PK/Pdt.Sus-BPSK/2016 tertanggal 15 Juni 2016, di dalam putusannya pada halaman 19, dalam pertimbangannya Mahkamah Agung menyatakan "bahwa pihak kreditur telah wanprestasi atas perjanjian tersebut, sehingga penyelesaiannya 
merupakan kewenangan Pengadilan Negeri bukan kewenangan BPSK”.

i) Putusan No 64 K/Pdt.Sus-BPSK/2016 tertanggal 18 Juni 2016, di dalam putusannya pada halaman 11 , dalam pertimbangannya Mahkamah Agung menyatakan "Bahwa dengan demikian hubungan yang terjadi adalah hubungan utang piutang yang dijamin dengan sertifikat fidusia dan apabila salah satu pihak wanprestasi maka penyelesaiannya dilakukan di Pengadilan Negeri dengan acara perdata biasa, bukan oleh BPSK seperti halnya dalam perkara ini”".

j) Putusan No 189 K/Pdt.Sus-BPSK/2016 tertanggal 3 Agustus 2016, didalam putusannya halaman 22, dalam pertimbangannya Mahkamah Agung menyatakan "Bahwa terlepas dari alasan kasasi, putusan Judex Facti/PENGADILAN NEGERI Rantau Prapat harus dibatalkan karena sengketa yang timbul dari adanya perjanjian kredit atau masalah wanprestasi tidak diadili oleh Pengadilan Negeri pada pemeriksaan tingkat keberatan tetapi harus diadili oleh Pengadilan Negeri pada pemeriksaan tingkat pertama karena BPSK tidak berwenang mengadili sengketa yang bersumber dari perjanjian kredit".

Berikut matriks dari beberapa putusan-putusan Mahkamah Agung di atas:

\begin{tabular}{|c|c|c|c|c|}
\hline No & $\begin{array}{l}\text { Nomor } \\
\text { Putusan }\end{array}$ & Tanggal & $\begin{array}{c}\text { Kutipan Kalimat } \\
\text { MA }\end{array}$ & $\begin{array}{l}\text { BPSK } \\
\text { Kota }\end{array}$ \\
\hline 1 & $\begin{array}{c}\text { Putusan No } \\
572 \\
\text { K/Pdt.Sus- } \\
\text { BPSK/2014 }\end{array}$ & $\begin{array}{c}18 \\
\text { November } \\
2014\end{array}$ & $\begin{array}{l}\text { Pertimbangan MA } \\
\text { menyimpulkan } \\
\text { "bahwa masalah } \\
\text { yang diselesaikan } \\
\text { oleh BPSK } \\
\text { Bengkayang telah } \\
\text { berada "diluar" } \\
\text { kewenangan yang } \\
\text { diberikan } \\
\text { kepadanya". (hal 30) }\end{array}$ & $\begin{array}{c}\text { BPSK } \\
\text { Kota } \\
\text { Singkawa } \\
\text { ng }\end{array}$ \\
\hline 2 & Putusan No & 17 & Pertimbangan $\mathrm{MA}$ & BPSK \\
\hline
\end{tabular}




\begin{tabular}{|c|c|c|c|c|}
\hline & $\begin{array}{c}472 \\
\text { K/Pdt.Sus- } \\
\text { BPSK/2014 }\end{array}$ & $\begin{array}{c}\text { Februari } \\
2015\end{array}$ & \begin{tabular}{lr}
\multicolumn{3}{l}{ menyatakan "bahwa } \\
Badan Penyelesaian \\
Sengketa Konsumen \\
(BPSK) & Kota \\
Tasikmalaya & tidak \\
berwenang & untuk \\
memeriksa & dan \\
mengadili perkara \\
ini". (hal 14)
\end{tabular} & $\begin{array}{c}\text { Kota } \\
\text { Tasikmal } \\
\text { aya }\end{array}$ \\
\hline 3 & $\begin{array}{c}\text { Putusan No } \\
25 \\
\text { K/Pdt.Sus- } \\
\text { BPSK/2015 }\end{array}$ & $\begin{array}{l}27 \text { Maret } \\
2015\end{array}$ & \begin{tabular}{lr}
\multicolumn{2}{l}{ Pertimbangannya } \\
MA menyatakan \\
"bahwa & dengan \\
demikian & BPSK \\
tidak berwenang \\
mengadili perkara \\
perselisihan & yang \\
timbul & dari \\
perjanjian & kredit \\
atau & masalah \\
wanprestasi". (hal 7)
\end{tabular} & $\begin{array}{l}\text { BPSK } \\
\text { Kota } \\
\text { Tasikmal } \\
\text { aya }\end{array}$ \\
\hline 4 & $\begin{array}{c}\text { Putusan No } \\
341 \\
\text { K/Pdt.Sus- } \\
\text { BPSK/2015 }\end{array}$ & $\begin{array}{l}18 \text { Juni } \\
2015\end{array}$ & 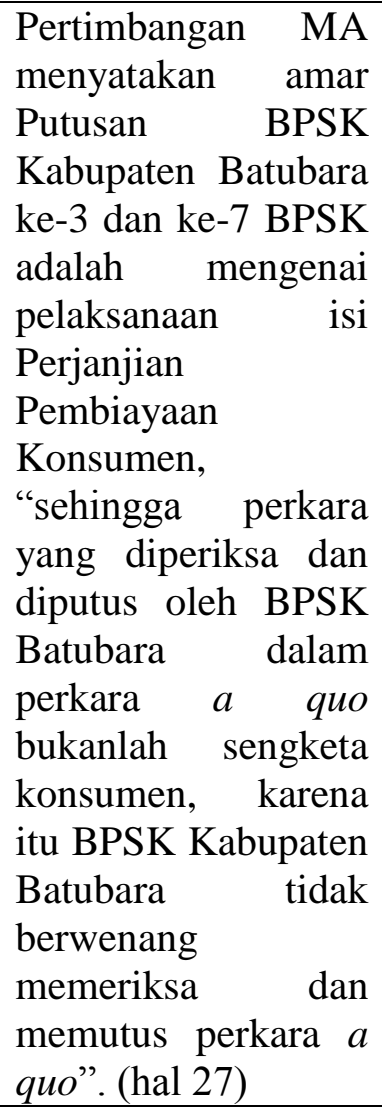 & $\begin{array}{c}\text { BPSK } \\
\text { Kabupate } \\
\text { n } \\
\text { Batubara }\end{array}$ \\
\hline 5 & $\begin{array}{l}\text { Putusan No } \\
549 \\
\text { K/Pdt.Sus- }\end{array}$ & $\begin{array}{c}22 \\
\text { Oktober } \\
2015 \\
\end{array}$ & \begin{tabular}{lr}
\multicolumn{2}{l}{ Pertimbangannya } \\
MA & menyatakan \\
"BPSK & tidak \\
\end{tabular} & $\begin{array}{l}\text { BPSK } \\
\text { Kota } \\
\text { Padang }\end{array}$ \\
\hline
\end{tabular}




\begin{tabular}{|c|c|}
\hline BPSK/2015 & $\begin{array}{lr}\text { memiliki } & \\
\text { kewenangan } & \text { untuk } \\
\text { mengadili } & \\
\text { perselisihan } & \text { yang } \\
\text { timbul } & \text { dari } \\
\text { Perjanjian } & \text { Kredit } \\
\text { dengan } & \text { jaminan } \\
\text { karena perselisihan } \\
\text { tersebut r tidak } \\
\text { termasuk } & \text { sengketa } \\
\text { konsumen } & \text { dan } \\
\text { produsen yang diatur } \\
\text { dalam r Undang- } \\
\text { Undang } \\
\text { Perlindungan } \\
\text { Konsumen". (hal 12) }\end{array}$ \\
\hline
\end{tabular}

Penerapan dan pandangan Mahkamah Agung mengenai pembatasan kewenangan BPSK dapat dilihat dari putusan-putusan Mahkamah Agung selama beberapa tahun terakhir seperti yang telah dipaparkan dalam putusan-putusan di atas. Putusan-putusan Mahkamah Agung tersebut telah menunjukan sikap hukum Mahkamah Agung yang konsisten, bahwa BPSK tidak berwenang menyelesaikan sengketa yang timbul dari pelaksanaan perjanjian pembiayaan kredit dengan jaminan fidusia ataupun hak tanggungan, dan wewenang untuk mengadili dan memutus sengketa yang timbul dari pelaksanaan perjanjian pembiayaan kredit dengan jaminan fidusia ataupun hak tanggungan merupakan wewenang Pengadilan Negeri.

\section{PENUTUP}

\section{A. Kesimpulan}

Berdasarkan uraian analisis yang telah penulis uraikan diatas, maka dapat ditarik kesimpulan berupa:

1. Kewenangan BPSK menyelesaikan perkara perlindungan konsumen dibatasi dengan adanya perjanjian yang dilakukan oleh 
konsumen dan pelaku usaha. Artinya BPSK tidak memiliki kewenangan menyelesaian sengketa perlindungan konsumen yang didasari oleh perjanjian, melainkan menjadi kewenangan Pengadilan Negeri. Hal ini didasari pada Pasal 1338 KUHPer yang menegaskan bahwa semua perjanjian yang dibuat secara sah berlaku sebagai undang-undang bagi mereka yang membuatnya.

2. Penerapan pelaksanaan kewenangan BPSK tersebut terlihat dalam putusan-putusan Mahkamah Agung, antara lain Putusan Nomor 572 K/Pdt.Sus-BPSK/2014, Putusan Nomor 472 K/Pdt.SusBPSK/2014, Putusan Nomor 25 K/Pdt.Sus-BPSK/2015, Putusan Nomor 341 K/Pdt.Sus-BPSK/2015, Putusan Nomor 549 K/Pdt.Sus-BPSK/2015, Putusan Nomor 770 K/Pdt.SusBPSK/2015, Putusan Nomor 188 K/Pdt.Sus-BPSK/2016, Putusan Nomor 56 PK/Pdt.Sus-BPSK/2016, Putusan Nomor 64 K/Pdt.Sus-BPSK/2016, Putusan Nomor 189 K/Pdt.SusBPSK/2016, serta Putusan Nomor 481 K/Pdt.Sus-BPSK/2015 dan pandangan Mahkamah Agung mengenai pembatasan kewenangan BPSK dapat di lihat dari putusan-putusan Mahkamah Agung selama beberapa tahun terakhir seperti yang telah dipaparkan. Putusan-putusan Mahkamah Agung tersebut telah menunjukan sikap hukum Mahkamah Agung yang konsisten, bahwa BPSK tidak berwenang menyelesaikan sengketa yang timbul dari pelaksanaan perjanjian pembiayaan kredit dengan jaminan fidusia ataupun hak tanggungan, dan wewenang untuk mengadili dan memutus sengketa yang timbul dari pelaksanaan perjanjian pembiayaan kredit dengan jaminan fidusia ataupun hak tanggungan merupakan wewenang Pengadilan Negeri.

\section{B. Saran}

Bagi BPSK, seharusnya BPSK sebagai sebuah badan yang bertugas menangani dan menyelesaikan sengketa antara pelaku usaha dan 
konsumen, lebih memahami dan memperhatikan mengenai batas-batas kewenangannya dalam menangani suatu sengketa konsumen. Jika suatu sengketa yang diajukan kepada BPSK didasari pada suatu perjanjian, baik itu perjanjian jual pembiayaan, perjanjian jual beli ataupun perjanjian lain yang diakui dalam peraturan perundang-undangan, maka sudah sepatutnya jika BPSK menolak dan menyatakan tidak berwenang untuk menangani sengketa konsumen tersebut, hal ini di karenakan berdasarkan Pasal 1338 KUHPer menyatakan bahwa suatu perjanjian yang dibuat secara sah berlaku sebagai undang-undang bagi mereka yang membuatnya. Selain itu, majelis BPSK yang menangani suatu sengketa haruslah memperhatikan dan mempertimbangkan peraturan perundangundangan mana yang seharusnya digunakan pada saat memberikan suatu putusan sesuai dengan asas Lex specialis derogat legi generali, dan tidak hanya terpaku kepada UUPK semata.

\section{Daftar Pustaka}

\section{A. Buku}

Diantha, I Made Pasek. Metodologi Penelitian Hukum Normatif Dalam Jutifikasi Teori Hukum. (Jakarta: Kencana Prenada Media Group, 2016).

Fuady, Munir. Konsep Hukum Perdata. (Jakarta: PT RajaGrafindo Persada, 2014).

Nugroho, Susanti Adi, Proses Penyelesaian Sengketa Konsumen Ditinjau Dari Hukum Acara Serta Kendala Implementasinya. (Jakarta: kencana, 2008).

Miru, Ahmadi. Prinsip-Prinsip Perlindungan Hukum Bagi Konsumen Di Indonesa. (Jakarta: PT RajaGrafindo Persada, 2013).

Shidarta, Hukum Perlindungan Konsumen Indonesia. (Jakarta: PT Grasindo, 2006).

Soekanto, Soerjono. Pengantar Penelitian Hukum. (Jakarta: UI Press, 1986). 
Soekanto, Soerjono dan Sri Mamudji. Penelitian Hukum Normatif.

Cetakan ke-1. (Jakarta: PT RajaGrafindo Persada, 2006).

Sularsi. Penyelesaian Sengketa Konsumen Dalam Undang-Undang

Perlindungan Konsumen. (Jakarta: Yayasan Lembaga Konsumen

Indonesia, 2001).

Sutedi, Andrian. Tanggung Jawab Produk Dalam Hukum Perlindungan Konsumen. (Bogor: Ghalia Indonesia, 2008).

\section{B. Website}

Anonim,"Perlindungan Hak-Hak Konsumen Listrik Di Indonesia Menurut Undang-Undang Nomor 8 Tahun 1999 Tentang Perlindungan Konsumen", https://ayobelajarhaki.wordpress.com/2012/05/04/perlindungan-hakhak-konsumen-listrik-di-indonesia-menurut-undang-undang-nomor8-tahun-1999-tentang-perlindungan-konsumen/, diakses tanggal 4 Mei 2008.

Kolom Arsil,"Sikap Hukum MA atas Kewenangan BPSK Mengadili Sengketa Lembaga Pembiayaan dan Nasabah", http://www.hukumonline.com/berita/baca/lt59f2b4473d8f0/sikap-hukumma-atas-kewenangan-bpsk-mengadili-sengketa-lembaga-pembiayaan-dannasabah, 27 Oktober 2017.

Naringgoyudo, "Perbedaan Deduktif dan Induktif", https://naringgoyudo.wordpress.com/2015/03/24/perbedaan-deduktif-daninduktifı, diakses tanggal 24 Maret 2015. 